\title{
Mangrove use and management within the Sine-Saloum Delta, Senegal
}

\author{
Laura Gallup $^{\text {a,1,**, David A. Sonnenfeld }}{ }^{\text {a }}$, Farid Dahdouh-Guebas ${ }^{\mathrm{b}, \mathrm{c}, \mathrm{d}}$ \\ ${ }^{a}$ State University of New York College of Environmental Science and Forestry (ESF), 1 Forestry Drive, Syracuse, NY, United States \\ ${ }^{\mathrm{b}}$ Systems Ecology and Resource Management Research Unit, Universite Libre de Bruxelles (ULB), Avenue. F.D. Roosevelt 50, CPi 264/1, B-1050, Brussels, Belgium \\ ${ }^{\mathrm{c}}$ Ecology \& Biodiversity Research Unit Department of Biology Vrije Universiteit Brussel (VUB), Pleinlaan 2, B-1050, Brussels, Belgium \\ ${ }^{\mathrm{d}}$ Mangrove Specialist Group, International Union for the Conservation of Nature (IUCN), Conservation Programmes, Zoological Society of London, Regents Park, \\ London, NW1 4RY, UK
}

\section{A R T I C L E I N F O}

\section{Keywords:}

Coastal management

Community-based natural resource

management

Fuelwood harvesting

Mangrove reforestation

West Africa

\begin{abstract}
A B S T R A C T
Laura Gallup, David A. Sonnenfeld, Farid Dahdouh-Guebas. Mangrove use and management within the SineSaloum Delta, Senegal. 2019.

Mangroves constitute one of the most complex and productive ecosystems in the world. This study explores mangrove use and management within the Sine-Saloum Delta, Senegal. It utilizes field-based, mixed research methods, drawing primarily on quantitative survey data, supplemented with qualitative data from semistructured interviews, personal communications with villagers, and participant observation from August-December 2013. Research results indicate that use of dead mangrove wood for fuelwood is the most important extractive use of mangroves within the Delta. Fish, clam, oyster, and shrimp collection is the second most important use of mangroves in the region. Senegal's Forest Code Law notwithstanding, ambiguity remains in mangrove management and adequate means are lacking for protection of mangroves within the Delta. Study results show that mangrove reforestation is a robust activity in the region, and that financial incentives from international organizations and NGOs are significant in motivating community involvement. Study results suggest that mangrove plantings may have a low survival rate, however further investigation is needed.
\end{abstract}

\section{Introduction}

Approximately one-fifth of the world's mangroves are found in SubSaharan Africa, and $70 \%$ of these are found in West Africa (Corcoran et al., 2007). In West Africa, mangroves extend from Mauritania to Nigeria, encompassing an area of approximately 1,686,200 ha (Dia, 2012). In Senegal, mangroves can be found in four areas: the Sine-Saloum Delta, the Casamance, the mouth of the Senegal River, and Joal. The Sine-Saloum Delta (Fig. 1) is located in an inter-tropical zone on the coast of Senegal, approximately $100 \mathrm{~km}$ south of Dakar, the capital (Dia, 2012). The Delta covers an area of approximately 180, 000 ha, $10 \%$ of Senegal's total land (Dia, 2012). It is comprised of several islands and three main, saline tributaries: the Saloum $(110 \mathrm{~km}$ long), Bandiala (18 km long), and Diomboss (30 km long) (Dia, 2012).

Seven species of mangroves are present throughout Senegal: Acrostichum aureum L.; Rhizophora mangle L.; Rhizophora racemosa Meyer; Rhizophora harisonnii Leechman; Laguncularia racemosa (L.) Gaertn.f.; Avicennia germinans (L.) Stearn; and Conocarpus erectus L. (Cisse et al.,
2004; Corcoran et al., 2007). All but Acrostichum aureum L. are found in the Sine-Saloum Delta (Ndour et al., 2012). Within the Delta, there is some differentiation among mangroves in three sub-regions, with the tallest trees (7-11 $\mathrm{m}$ in height) being present in the southern part, shorter trees (2-8 $\mathrm{m}$ in height) with signs of degradation in the central part, and extremely short (less than $4 \mathrm{~m}$ in height) and highly degraded trees to the point of disappearance in the northern part of the Delta (Dia, 2012).

Mangroves constitute one of the most complex and productive ecosystems in the world (Datta et al., 2012; Donato et al., 2011). Historically, local communities around the globe have used mangroves as sources of timber, food, charcoal, firewood and medicine (Bandaranayake, 1998; Kovacs, 1999; Walters et al., 2008). Mangroves also provide support functions to fisheries and are a source of habitat to a variety of wildlife. The two most common uses of mangrove wood is for fuel and construction (Walters et al., 2008). Mangroves, particularly the Rhizophora species, are often preferred for fuelwood and charcoal because they produce less smoke and burn longer and hotter than many

\footnotetext{
* Corresponding author. 22 Thomas Circle, Vergennes, VT, 05491, United States.

E-mail addresses: laura.c.gallup@gmail.com (L. Gallup), dsonn@esf.edu (D.A. Sonnenfeld), fdahdouh@ulb.ac.be (F. Dahdouh-Guebas).

1 Permanent address: 22 Thomas Circle, Vergennes Vermont 05491 United States.
} 
other woods (Bandaranayake, 1998; Balla Dieye et al., 2013; Walters et al., 2008). Within the Sine Saloum Delta region, it is estimated that from 1500 to 5700 individuals per hectare have been cutting mangrove wood (Ndour et al., 2012). In the Sine-Saloum Delta, mangroves support over 114 spawning and/or nursing fish species (Dia, 2012), and 15,000 tons of fish and shrimp, and 2600 tons of mollusks are produced annually (ADG, 2011). The Serere people are the predominant ethnic group in the Sine Saloum Delta (Cisse et al., 2004); however, the Serere Niominka and the Soce ethnic groups primarily inhabit the islands (Cisse et al., 2004; Fall and De, 2009). The Serere Niominka are the larger of the two ethnic groups (Conchedda et al., 2011), they live north of the Diomboss, in the Saloum (Gandoul) Islands (Cisse et al., 2004; Fall and De, 2009). The Soce live south of the Diomboss, in the Betenti (Soce) Islands (Cisse et al., 2004; Fall and De, 2009). For these two ethnic groups, fishing and fishing-related activities are of immense cultural and economic importance; and several villages specialize in fishing and fish processing (Cisse et al., 2004; Cormier-Salem, 1994; Fall and De, 2009; Weigel et al., 2011). While predominately Muslim, the Serere remain largely influenced by animism, based on the belief of Pangool, a spirit of the forest; and the Niominka strongly believe that the mangrove is a gift
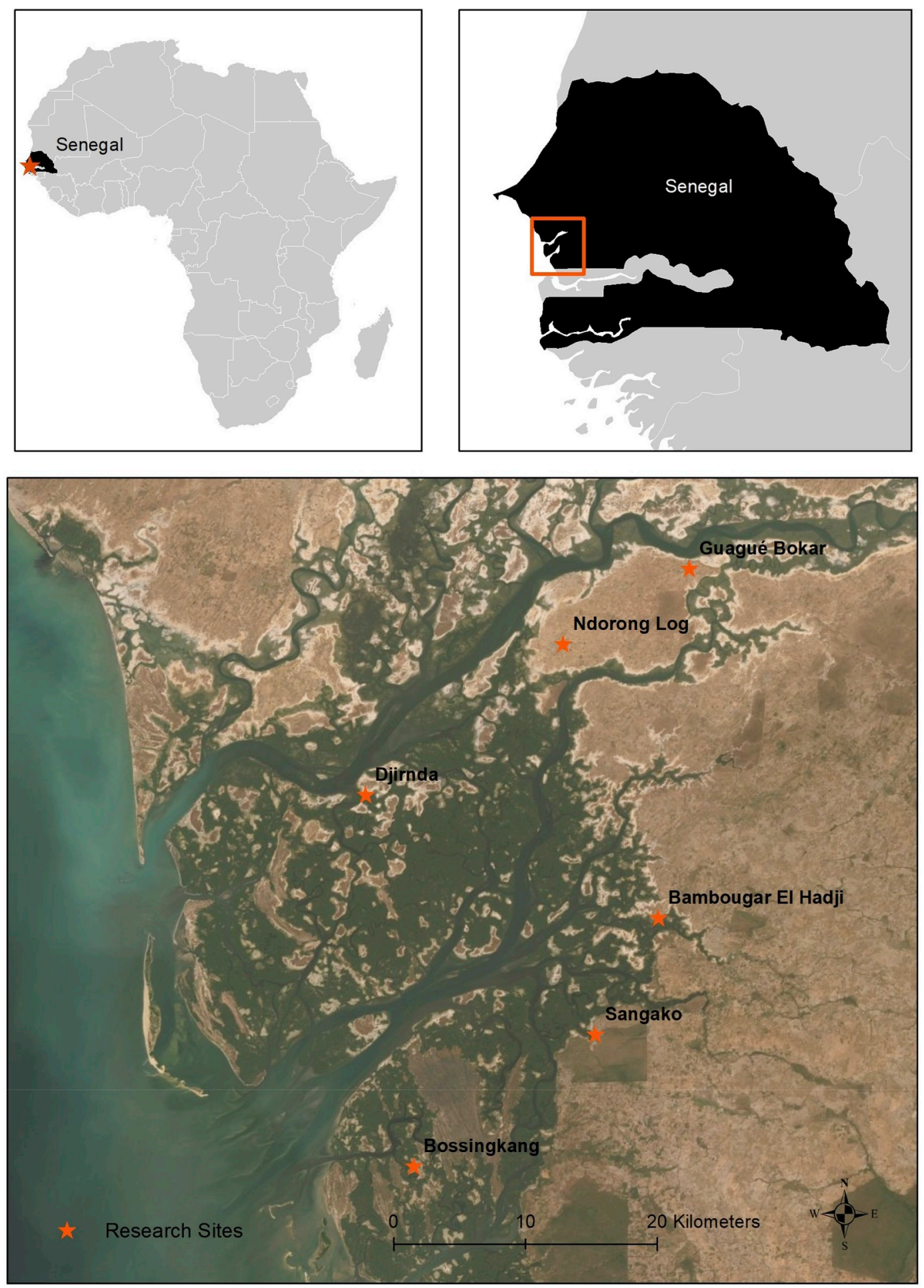

Fig. 1. Location of survey villages. (Map: Emiko Guthe). 
from God (Cisse et al., 2004).

Mangroves are one of the most threatened global ecosystems (Duke et al., 2007; Walters et al., 2008). Approximately one-third of the mangrove cover in the Sine Saloum Delta was lost between 1972 and 1986 (Conchedda et al., 2011; Balla Dieye et al., 2013; Fent et al., 2019). Although many factors are behind mangrove loss, humans largely contribute to the threatened state (Walters et al., 2008). In describing anthropogenic degradation of mangroves globally, six distinct categories have been found: (1) degradation resulting from extractive uses of mangrove trees and fauna (Ellison and Farnsworth, 1996; Romañach et al., 2018); (2) degradation of mangroves associated with reclamation for non-extractive uses (including the harvesting of fish, crab, shellfish, honey, wood, charcoal and tannins); the conversion of mangroves for agricultural, industrial and urban developments; and to create salt flats and shrimp ponds (Alongi et al., 2016; Cisse et al., 2004; Diop and Soumare, 1999; Ellison and Farnsworth, 1996; Ndour et al., 2012; Romañach et al., 2018; Valiela et al., 2001); (3) degradation resulting from the pollution of mangroves (Ellison and Farnsworth, 1996; Fall et al., 2009; Romañach et al., 2018); (4) degradation resulting from human-driven climate change (Ellison and Farnsworth, 1996); (5) degradation resulting from anthropogenic hydrological changes (Dahdouh-Guebas et al., 2005); and, (6) degradation resulting from the overgrazing by livestock (Dahdouh-Guebas et al., 2006).

A number of countries have placed mangrove protection firmly into policy guidelines or framework legislation. Laws that govern land use and the management of mangroves vary greatly across nations and even within nations (Lavieren et al., 2012; Weigel et al., 2011; Weigel and Dahou, 2007). In Senegal, mangroves are governed under the Senegalese Forest Code Law n 98-03 and its Application Decree n 98-164 (Republique du Senegal, 1998). The Sine Saloum Delta mangroves are unique in that some areas are managed by the regulations of the Saloum Delta National Park and some areas are not (Weigel and Dahou, 2007). The application of regulations varies between Rural Communities and the services of the Ministry of Water and Forest, and when coupled with interventions by NGOs and development organizations there can be contradictory interpretations of these regulations (Weigel and Dahou, 2007).

Once mangroves are degraded, they are often permanently destroyed and may only be able to be rehabilitated under certain conditions (Bosire et al., 2008; Dahdouh-Guebas et al., 2004; Field, 1998; Kairo et al., 2001; Lewis and Gilmore, 2007; Walton et al., 2006). National governments, and numerous international organizations have supported mangrove rehabilitation programs, and steps have been taken to rehabilitate degraded mangroves in many different countries throughout the world. While there remains a tendency to emphasize mangrove reforestation as a primary tool in rehabilitation (Bosire et al., 2008), there are additional activities that are essential for successful mangrove rehabilitation. These activities include identification of the causes of degradation at the site (Datta et al., 2012; Field, 1998; Walters et al., 2008), selection of appropriate rehabilitation sites (Datta et al., 2012; Field, 1998; Walters et al., 2008), species selection (Kairo et al., 2001; Nguyen et al., 2017, 2016; Walters et al., 2008), timely planting, regular monitoring (Field, 1998; Kairo et al., 2001) and the involvement of local communities and governments (Field, 1998; Kairo et al., 2001; Romañach et al., 2018; Stone et al., 2008; Walters et al., 2008).

In the Sine Saloum Delta, there has been a push since the 1990s by various national and international agencies to rehabilitate the mangrove ecosystem (Ndour et al., 2012). Reforestation programs within the Delta have included those sponsored by government agencies and national and international organizations such as the United Nations Food and Agriculture Organization (FAO), the International Union for Conservation of Nature (IUCN), the West African Association for Marine Environment (WAAME), the World Wildlife Fund/West Africa Program Office (WWF/WAMPO), the Japan International Cooperation Agency (JICA), the United States Peace Corps, and many others. In addition, in exchange for carbon credits under REDD (Reduced Emissions from
Deforestation and Forest Degradation) climate-mitigation mechanisms, several European food and utility companies have sponsored reforestation projects in Senegal (Carney et al., 2014). One company carried out a "Plant Your Tree" initiative between 2006 and 2012. This effort mobilized over 300,000 people to participate in what was claimed to be "the largest restoration program in the world" (Cormier-Salem and Panfili, 2016; Sall and Durin, 2013). More than $1400 \mathrm{~km}^{2}$ of Rhizophora spp. were reported to have been replanted within the Sine-Saloum Delta and Casamance regions of Senegal under this initiative (Cormier-Salem, 2017).

This study examines mangrove use and management within the SineSaloum Delta, Senegal. The use of mangrove wood (dead wood and green wood), leaves, fruit and roots are examined along with the use of fish, oysters, shrimp, clams, honey, salt and shells. Mangrove management, particularly in regard to regulations and participation in mangrove reforestation activities is discussed as well.

\section{Methods}

Data for this study were gathered in the Sine-Saloum Delta, Senegal, from August to December 2013. A field-based, mixed method approach involving the collection, analysis and integration of quantitative (survey) and qualitative (semi-structured interviews, personal communications with villagers, and participant observation) research was utilized. This study draws primarily on quantitative survey data, supplemented with qualitative data obtained from interviews, personal communications with villagers and other informants, and participant observations.

\subsection{Participant observation}

The lead author engaged in participant observation through a fourmonth Program Officer assignment with Peace Corps Senegal/Peace Corps Response, in partnership with Senegal's Ministry of Environment, Waters and Forests; and in collaboration with World Wildlife Fund's (WWF) West African Marine Eco-Region (WAMER) program. During this assignment, the lead author conducted research while based at the WWF office in the village of Foundiougne, Senegal, and participated in mangrove reforestation events organized by World Wildlife Fund and Peace Corps Senegal.

\subsection{Survey}

A questionnaire consisting of structured and open-ended questions was utilized. It was written in Wolof, the most widely spoken language in Senegal, and was interviewer-administered in the Wolof language with the responses written down on paper. One limitation to this method was that some households may have selected informants based on their knowledge of Wolof, resulting in potentially fewer insights from nonWolof speaking members of the household. In order to gain access into villages and trust from the community, a community member accompanied the interviewer while surveys were being conducted. One village was predominately Soce speaking, and a translator assisted to facilitate communication. The goal for the survey was to sample 20 adult men and 20 adult women from each of six villages, for a total of 240 informants. Ultimately, 219 surveys were completed, with two smaller villages each providing fewer than 40 responses.

Villages were selected based on their location along the Delta and interviewer access to the villages. Villages were also selected to be located with an equal distribution of sites to the North and South of the Delta, and to include both mainland and island villages. This was done in order to examine mangrove use in areas with different ethnic enclaves and to sample areas where mangrove species and prevalence differed.

The number of households surveyed in each village were chosen by dividing the total number of households by 40 . Only one person per household was selected and sampling alternated between male and female respondents to increase randomness. To increase the response rate 
and reduce the time spent in each village, the choice of respondent was decided upon by members of each household. The only requirements were that they had to be 18 years of age or older, and had to reside within the household. In one village with fewer than 40 households, 20 adult women and 17 adult males in $100 \%$ of the households were sampled. In a second village that had fewer than 40 households, 12 adult females and 10 adult males were selected from 27 households. The lower sample size for the second village was attributed to survey administration coinciding with field crop harvesting.

The validity and reliability of the survey instrument was increased by pre-testing the questionnaire and by confirming translations with Senegalese mangrove experts and native Wolof speakers. During pretesting, it was found to be culturally inappropriate to ask participants their gender, therefore participant gender was determined by the interviewer based upon observation and interpretation. Following pretesting, adjustments were made to the structure of the questionnaire, the order of questions, and the types of questions asked.

For determining mangrove knowledge, participants originally were shown images of various tree species, together with their respective propagules and fruit. However, some respondents reported never having seen the species before, even when that particular species was observable near the village; or they named a different species altogether. Thinking that some villagers might have difficulties with their vision or that the images were unclear, samples of mangrove species were used as an accompaniment to the photographs. When the participants were able to touch and smell the samples, there was a noticeable improvement in the validity and reliability. If participants still did not know the species, then the interviewer stated the name of the species; and it was at this point that the interviewer marked whether someone knew the species or not. Respondent responses to follow-up questions and triangulation of information received through interviews and observations helped the interviewer determine if the participant did in fact know the species or not.

For determining collection frequency, participants often would state that they collect items every day. However, when the interviewer informally asked, "did you collect that item today?" some respondents replied that they did not, because there was a baptism, wedding, funeral, bad weather, etc., preventing them from going that day. To correct for this and to assist with data analysis, the question was changed to "how many times per week do you collect the item", and frequency was categorized into low, medium, and high frequencies of collection. This categorization helped adjust for such circumstances. To describe collection frequency, the following categorizations were utilized: Low frequency of collection (Rarely; and 1-11 days per year), Medium frequency of collection (12-52 days per year), High frequency of collection (53 or more days per year).

Survey data were numerically coded and analyzed using SPSS and Excel software. Descriptive statistics were used to analyze the data.

\subsection{Interviews}

Semi-structured, face-to-face interviews were used to validate information received from the surveys and to provide additional information about mangrove use and management. To achieve this, two sets of interview questions were developed. One set of questions was designed for village chiefs and key community members; the second was designed for informants affiliated with governmental, nongovernmental, and other organizations. A total of 35 interviews were conducted, including 23 interviews with village chiefs and key community members, and 12 from organizationally affiliated informants. Eleven of the interviewees were female, and 24 were male.

Sampling procedures used for the interviews were based on nonprobabilistic, purposive (Tongco, 2007) and snowball (Goodman, 1961) methodologies, respectively. Interviewees included the village chief, heads of groups that worked with mangrove and mangrove ecosystem resources in the villages surveyed; and individuals affiliated with governmental agencies, international development organizations, and NGOs in Senegal that work with mangrove and mangrove ecosystem resources. After interviewing the village chief, snowball sampling was employed to find heads of groups that work with mangroves and mangrove ecosystem resources. The village chief identified groups that had been participating in mangrove-related activities, and their leaders.

\section{Results}

The villages where surveys were administered ranged in size from approximately 400 to 2729 residents. Survey respondents were Muslim (99.1\%) and their ethnicities varied across villages (see Table 1). Survey respondents were 44 years old on average, and mostly uneducated. Over half of all respondents were without any formal education, Most respondents lived their entire lives within their village.

\subsection{Mangrove use}

Mangroves are a critical economic and material resource for residents of the Sine-Saloum Delta (see Fig. 2). Almost all survey respondents stated that mangroves are 'very important' to their livelihood, and results indicate that mangroves are used in a variety of ways (see Table 3). The most dominant mangrove species in the Sine-Saloum Delta are the Rhizophora species which cover $25 \%$ of the Delta, and Avicennia germinans which cover about $75 \%$ of the Delta (Interview, August 2013). These species are the most well-known species to survey participants, and villagers referred to them by their local language name (see Table 2), as paletuvier (the French word for mangrove), or by their Latin scientific name when speaking about them. No differentiations were made between Rhizophora species. Mangroves of the Laguncularia racemosa and Conocarpus erectus species were known to a far lesser degree by survey participants. There are no Wolof words for the Laguncularia racemosa or Conocarpus erectus species, and there was much uncertainty among the respondents regarding the correct name of the species in the Serere and Soce languages. In the Soce language, the latter two species were most often referred to as manco cena, which translates to "cousin of the mangrove".

\subsubsection{Dead wood}

Dead wood is the most used and collected mangrove resource in the Sine-Saloum Delta. Survey results indicate that dead mangrove wood is used by $89 \%$ of households (n 219), with use reaching $100 \%$ in two villages. The dead wood is used primarily as a fuel source, however it is also a source of income, with $15.1 \%$ of survey respondents stating that someone in their household has sold it, and $36.1 \%$ stating that someone in their household has purchased it.

Firewood is the primary source of fuel used for cooking in much of Senegal, and within the Sine-Saloum Delta. The type of trees that are available in a particular area has a direct impact on the type of wood that is used as firewood. According to an Environmental Agent in Senegal, "people [in the Sine-Saloum Delta] use mangroves because many of the villages are islands and there are no other trees besides mangroves to use" (Interview, August 2013). In one village it was stated that, "people use mangrove wood to cook because there is no other wood. It is hard for people to use other wood for cooking because there isn't much land to plant other types of trees" (Interview, September 2013). In villages that are relatively distanced from the mangroves people may use other types of wood (apart from mangroves). According to one woman, people "don't use mangrove wood to cook, they use other plants such as eucalyptus. There are no mangroves available in the area to cook [with]" (Interview, September 2013).

Most households (65\%; $n \quad 219)$ reported that they use any type of wood for fuelwood (mangrove and non-mangrove), however, 19\% stated that they exclusively use mangrove wood. Island villages report the highest exclusive use of mangrove firewood $(60 \% \mathrm{n} \quad 40$, and $35 \%$ $\mathrm{n}$ 40). Rhizophora spp. is the preferred species of mangrove for 
Table 1

Description of study villages and survey respondents. (Source: Survey results).

\begin{tabular}{|c|c|c|c|c|c|c|c|}
\hline Village & Ndorong Log & Guague Bocar & Djirnda & Sangako & Bossingkang & Bambougar El Hadji & Totals \\
\hline Rural community & Mbam & Mbam & Djirnda & Toubacouta & Toubacouta & Diossong & - \\
\hline Village population & 1209 & 800 & 2729 & 1500 & 1053 & 400 & - \\
\hline Households in village & 104 & 79 & 200 & 37 & 80 & 27 & - \\
\hline Survey respondents & 40 & 40 & 40 & 37 & 40 & 22 & 219 \\
\hline Female survey respondents & 20 & 20 & 20 & 20 & 20 & 12 & 112 \\
\hline Males survey respondents & 20 & 20 & 20 & 17 & 20 & 10 & 107 \\
\hline Mean age of survey respondents & 45 & 43 & 47 & 46 & 43 & 41 & 44 \\
\hline Niominka Serere ethnicity & $0 \%$ & $2.5 \%$ & $95 \%$ & $2.7 \%$ & $2.5 \%$ & $95.5 \%$ & $28.3 \%$ \\
\hline Serere (non-Niominka) ethnicity & $97.5 \%$ & $35 \%$ & $2.5 \%$ & $94.6 \%$ & $0 \%$ & $0 \%$ & $40.6 \%$ \\
\hline Soce ethnicity & $2.5 \%$ & $2.5 \%$ & $0 \%$ & $2.7 \%$ & $92.5 \%$ & $0 \%$ & $18.3 \%$ \\
\hline Pulaar ethnicity & $0 \%$ & $42.5 \%$ & $0 \%$ & $0 \%$ & $2.5 \%$ & $4.5 \%$ & $8.7 \%$ \\
\hline Wolof ethnicity & $0 \%$ & $15 \%$ & $0 \%$ & $0 \%$ & $0 \%$ & $0 \%$ & $2.7 \%$ \\
\hline Other ethnicity & $0 \%$ & $2.5 \%$ & $2.5 \%$ & $0 \%$ & $2.5 \%$ & $0 \%$ & $1.5 \%$ \\
\hline
\end{tabular}

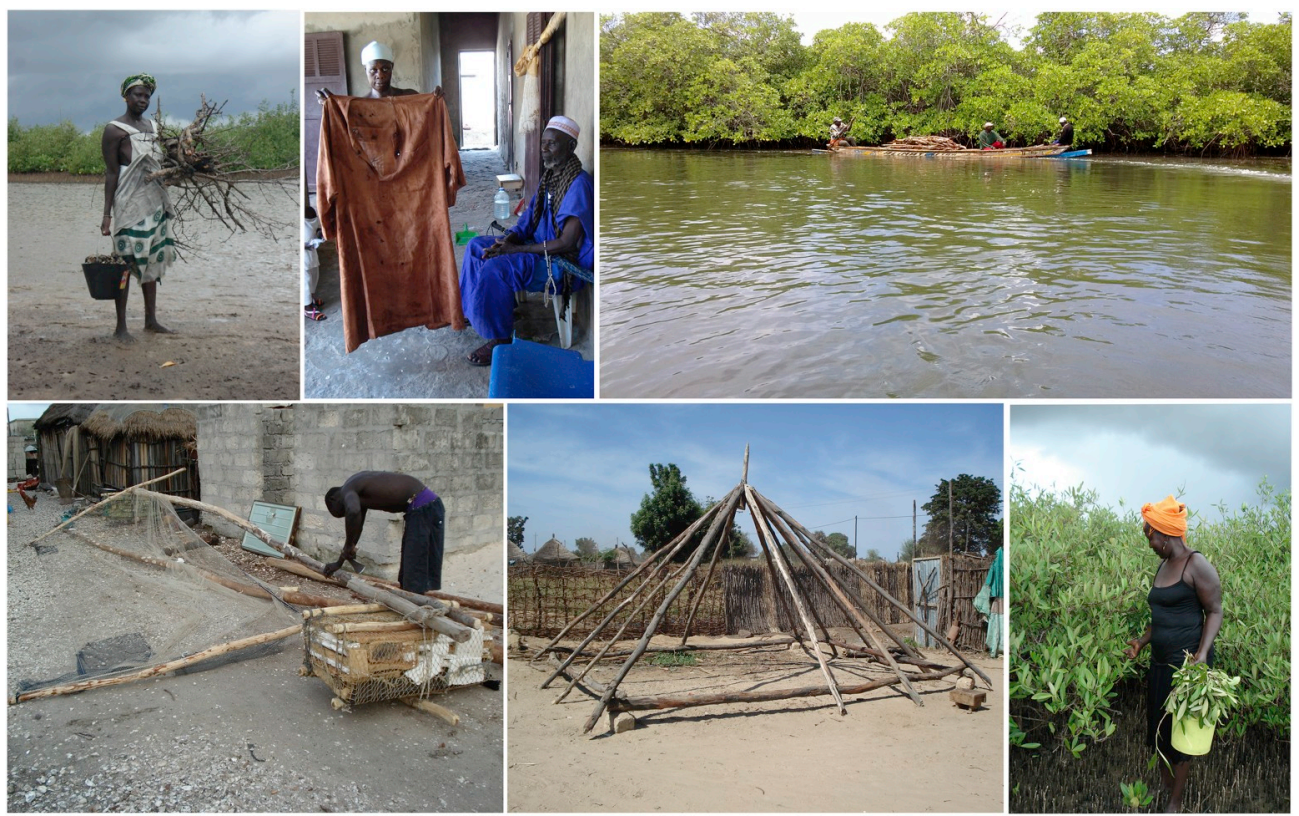

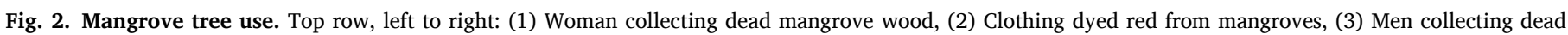

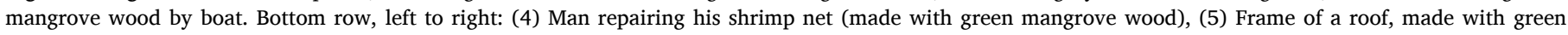
mangrove wood, (6) Woman collecting Avicennia germinans leaves. (Photographs: Laura Gallup).

Table 2

Local language names of mangroves in the Sine-Saloum Delta, Senegal (Source: Survey).

\begin{tabular}{lllll}
\hline Language & $\begin{array}{l}\text { Rhizophora } \\
\text { spp. }\end{array}$ & $\begin{array}{l}\text { Avicennia } \\
\text { germinans }\end{array}$ & $\begin{array}{l}\text { Conocarpus } \\
\text { erectus }\end{array}$ & $\begin{array}{l}\text { Laguncularia } \\
\text { racemosa }\end{array}$ \\
\hline Wolof & Mangli; & $\begin{array}{l}\text { Avicennia } \\
\text { germinans }\end{array}$ & n/a & n/a \\
& Mang & Mbungand & Nara; & Ndas fall; \\
Serere & Ndas; & Ndam; & Bak \\
& Ndasli & & $\begin{array}{l}\text { Ndaram; } \\
\text { Ndamb gere }\end{array}$ & \\
Soce & Manco & Dubo khun & Manco cena & $\begin{array}{l}\text { Cacha rolen; } \\
\text { Manco cena }\end{array}$ \\
\hline
\end{tabular}

fuelwood use because it is said to burn longer and hotter than many other woods, emit less smoke than other wood, and burn easier during the rainy season. For those reasons Rhizophora spp. is also said to be the preferred type of fuelwood for smoking fish caught by migrant fishermen. These fishermen utilize the wood in drying ovens to smoke the fish they catch prior to transporting it back to their home country.
Dead mangrove wood is collected at a high frequency with $26 \%$ of respondent households collecting it at a high frequency (53 or more days of the year) and $40 \%$ (n 219) collecting it at a medium frequency (between 12 and 52 days of the year). One village has 58\% (n 40) collecting mangrove wood at a high frequency. The amount of firewood collected depends on many factors, including household size, proximity to the mangroves, and the time of year. People collect larger pieces and greater quantities before the rainy season because it is more difficult to find dry wood during the rainy season. In addition, one male survey participant stated that women tend to collect smaller quantities of mangrove firewood twice per month, whereas men go once every six months with a boat and collect a larger quantity.

Mangrove firewood is purchased typically in a "charge" which is a donkey cart or boat filled with wood, or in a 'stere' (1 cubic meter) of wood. When sold or purchased, dead mangrove wood fetches a higher price than dead wood from other non-mangrove species. In the islands, it is common for large quantities of dead mangrove wood to be sold to migrant fishermen who reside there seasonally. One survey participant stated that he sold one canoe load of mangrove firewood to migrant fishermen in the present year, and that he sold them 30 loads of 
Table 3

Summary of mangrove uses in the Sine-Saloum Delta. (Source: Survey results).

\begin{tabular}{|c|c|c|c|c|}
\hline & \multicolumn{4}{|l|}{ Mangrove species } \\
\hline & Rhizophora spp. & Avicennia germinans & $\begin{array}{l}\text { Conocarpus } \\
\text { erectus }\end{array}$ & $\begin{array}{l}\text { Laguncularia } \\
\text { racemosa }\end{array}$ \\
\hline $\begin{array}{l}\text { Dead } \\
\text { Wood }\end{array}$ & $\begin{array}{l}\text { Firewood: for cooking, to keep mosquitoes away, for } \\
\text { smoking fish } \\
\text { Source of income }\end{array}$ & $\begin{array}{l}\text { Firewood: for cooking } \\
\text { Source of income }\end{array}$ & $\begin{array}{l}\text { Firewood: for } \\
\text { cooking }\end{array}$ & $\begin{array}{l}\text { Firewood: for } \\
\text { cooking }\end{array}$ \\
\hline $\begin{array}{l}\text { Green } \\
\text { wood }\end{array}$ & $\begin{array}{l}\text { Lumber: Posts for clotheslines, fencing, housing, to hold } \\
\text { up trees heavy with fruit, to tie up animals, fishing poles, } \\
\text { poles for shrimp nets, Sailboat mast, canoes, } \\
\text { Furniture: seating, } \\
\text { Tools: Handles for farming tools, food preparation tools } \\
\text { Source of income }\end{array}$ & $\begin{array}{l}\text { Medicine: the bark is used to treat stomachache, during } \\
\text { childbirth, and to induce labor }\end{array}$ & $\mathrm{n} / \mathrm{a}$ & $\mathrm{n} / \mathrm{a}$ \\
\hline Green & branches & $\begin{array}{l}\text { Lumber: beams for housing, roofing, fencing, } \\
\text { Tools: agricultural, fishing, cooking, preparing food, boat } \\
\text { paddle, Poles for fish and shrimp nets } \\
\text { Posts: clothes lines, to hold animals, to hold up trees heavy with } \\
\text { fruit } \\
\text { Medicine: to treat malaria } \\
\text { Source of income }\end{array}$ & $\mathrm{n} / \mathrm{a}$ & $\mathrm{n} / \mathrm{a}$ \\
\hline \multicolumn{5}{|l|}{$\mathrm{n} / \mathrm{a}$} \\
\hline Leaf & $\begin{array}{l}\text { Dye for clothing } \\
\text { Mystical purposes: to improve crops, to have higher } \\
\text { yields of fish and shrimp, to have higher sales of products, } \\
\text { to protect from the sea } \\
\text { Medicine: a tea is made to treat colds, steamed to treat } \\
\text { malaria } \\
\text { Glue for boats }\end{array}$ & $\begin{array}{l}\text { Consumption: A tea is made from it } \\
\text { Medicine: to treat body aches, malaria, during childbirth (before } \\
\text { and after), rashes, tooth ache, vision problems, fever, headaches, } \\
\text { fatigue, menstruation cramps and blood loss } \\
\text { Mystical purposes: to protect from the sea }\end{array}$ & $\mathrm{n} / \mathrm{a}$ & $\mathrm{n} / \mathrm{a}$ \\
\hline Fruit & $\begin{array}{l}\text { Medicine: to treat tooth aches, skin rashes, fever } \\
\text { Mystical purposes: to protect from the sea } \\
\text { Reforestation Consumption: a small part inside the fruit } \\
\text { can be eaten; it can be made into a beverage }\end{array}$ & $\begin{array}{l}\text { Consumption: it can be made into a sauce to be eaten with } \\
\text { millet, and made into a tea } \\
\text { Reforestation Medicine: to treat stomach ache }\end{array}$ & $\begin{array}{l}\text { Medicine: for } \\
\text { chickens }\end{array}$ & $\mathrm{n} / \mathrm{a}$ \\
\hline Roots & $\begin{array}{l}\text { Mystical purposes: helps protect from the sea, improves } \\
\text { crop yields, protects the household, protects fishermen } \\
\text { Tools: to remove oysters from roots, for cooking, to } \\
\text { remove snails from shells }\end{array}$ & $\begin{array}{l}\text { Medicine: To treat stomach ache, asthma, diarrhea, } \\
\text { menstruation cramps, Sexually transmitted infections, body } \\
\text { aches, tooth aches, childbirth (before and after), during } \\
\text { circumcisions } \\
\text { Consumption: Can be made into a tea, a small portion can be } \\
\text { eaten }\end{array}$ & $\mathrm{n} / \mathrm{a}$ & $\mathrm{n} / \mathrm{a}$ \\
\hline
\end{tabular}

mangrove firewood the year prior. Another survey participant stated that a small canoe full of mangrove firewood sold to migrant fishermen could fetch $\mathrm{XOF}^{2}$ 65,000; a medium-sized canoe, XOF 70,000; and a large canoe, XOF 100,000.

Traditional open-pit stoves are predominately used within the SineSaloum Delta for burning wood for cooking purposes, with some households using improved stoves, gas stoves, or mud stoves. Improved stoves are designed to consume less fuelwood than unimproved cooking stoves. Of the people who were surveyed, $14.6 \%$ (n 219) stated that they own an improved cooking stove. Improved cooking stoves are available in most weekly markets and ironsmith shops and are desired by most households, but they are expensive and most people cannot afford to purchase them outright. One international organization partnered with a number of local organizations within the Sine-Saloum Delta to bring improved cooking stoves to villagers through a micro-credit program. According to one interviewee, "Improved stoves cost XOF 4000 [But, through this program] every month you can pay XOF 1000 until the XOF 4000 is paid" (Interview, September 2013). Through this initiative, one village was able to secure 16 improved cooking stoves, and another village was able to secure 30 (Interview, September 2013).

\subsubsection{Green wood}

Twenty-one percent of survey respondent households (n 219) collect green mangrove wood at a medium frequency. Big, thick pieces of green mangrove wood and thinner green branches are used mostly as wood to build huts for housing, as shelters for animals, and for furniture

\footnotetext{
${ }^{2}$ International currency code for the West African CAF franc, official currency of Senegal and seven other West African states. XOF 500 \$1 USD (Oanda, 2014).
}

and tools. Rhizophora spp. is the only species of mangrove used as a green wood because its wood is said to be stronger than most other wood, it can grow long and in a uniform diameter, and because the wood is resistant to salt and termite damage. Green Rhizophora spp. wood also is used as a source of income. More households utilize thicker pieces of mangrove wood $(63 \%)$ than they do the thinner branches $(27 \%$; n 219).

Green Rhizophora spp. wood was observed for sale by two different vendors in the Kaolack regional market. The first vendor had approximately 20 pieces of mangrove wood for sale, and stated that the wood originated from The Gambia and the Sine-Saloum Delta. Each piece was approximately $4 \mathrm{~m}$ in length and $5 \mathrm{~cm}$ in diameter and priced at XOF 1000 . The second vendor had approximately 500 pieces of mangrove wood for sale, and stated that the wood originated from within the SineSaloum Delta. Prices for this wood ranged from XOF 850 to XOF 1000 for pieces that were approximately $4 \mathrm{~m}$ long, and $2 \frac{1}{2}-5 \mathrm{~cm}$ in diameter.

\subsubsection{Leaves, fruit and roots}

3.1.3.1. Leaves. Mangrove leaves, fruit, and roots are used primarily for consumptive, medicinal, and mystical purposes; and are used by $60 \%$ of survey respondents (n 219). Avicennia germinans leaves are often boiled and made into a hot breakfast beverage, similar to tea. Both Rhizophora spp. and Avicennia germinans leaves are known for their medicinal properties. Avicennia germinans leaves are massaged onto the body or made as a tea to relieve a variety of ailments including: tooth, head and body aches, menstrual cramping, pain associated with child birth, iron deficiencies, fever, and to help induce labor. Rhizophora spp. leaves can be steamed to treat malaria symptoms and made into a tea to help treat colds. 
Both types of leaves are also utilized for a variety of mystical purposes. Many people within the Sine-Saloum Delta believe in genies and spirits, and while many were reluctant to discuss the mystical uses of mangroves, several did state that fishermen often bathe in boiled $A v i-$ cennia germinans leaf water, steam their faces in it, or dye their clothes with Rhizophora spp. leaves before they go into the mangroves to protect themselves from the genies and spirits. It is also often believed that Rhizophora spp. leaves will increase fish and field crop yields when used in certain mystical ways.

Mangrove leaves are collected at a low frequency (1-11 days per year) by almost half of survey participants (46.1\%, n 219), and usually only on an as-needed basis. If funds are available, villagers stated that they are more apt to purchase medicine at pharmacies than they are to collect plants for treating maladies. Mangrove leaves are generally not sold or purchased, but if someone has a large quantity hey might accept a small amount of money from a neighbor for a handful of the leaves.

3.1.3.2. Propagules and fruit. Fifty-eight percent of survey respondents (n 219) use mangrove propagules and fruit. Rhizophora spp. propagules are primarily used for mystical and medicinal purposes. Fishermen often tuck a Rhizophora spp. propagule into their hat when they go fishing to protect themselves from genies and spirits; and if a child has a rash, parents will often tie a portion of a Rhizophora spp. propagule around the child's neck in an attempt to help the rash go away. Avicennia germinans fruit, on the other hand, is used for consumptive and medicinal purposes. The fruit of Avicennia germinans can be made into a sauce; and it can also be used to treat stomachaches. Both Rhizophora spp. and Avicennia germinans fruit and propagules are used for mangrove reforestation activities in the Sine-Saloum Delta. Conocarpus erectus fruit had one reported use to medicinally treat chickens; there were no reported uses of Laguncularia racemosa.

Similar to mangrove leaves, mangrove fruit and propagules are collected mostly on an as-needed basis. For the consumptive use of Avicennia germinans fruit, people stated that they traditionally depended on it as a food source, and that they eat it now primarily to re-create meals from the "old days", or if they don't have enough money to purchase other sources of food. Some villages have also been able to market traditional meals made with Avicennia germinans fruit to tourists that visit the islands. Mangrove propagules and fruit are generally not sold or purchased, except in the instance of mangrove reforestation events when organizations pay community members to collect Rhizophora spp. propagules. (see section 3.3.2.6 for more information).

3.1.3.3. Roots. Avicennia germinans and Rhizophora spp. roots are used in an array of ways by $31 \%$ of the households surveyed (n 219). Avicennia germinans pencil roots can be made into a tea, and a small portion of the root is known to have a sugary taste when eaten. Avicennia germinans roots are also used for medicinal purposes, and have been known to treat stomach, tooth and body aches; asthma, diarrhea, menstruation cramps, sexually transmitted infections, and pain associated with childbirth and circumcisions.

Rhizophora spp. prop roots are principally used for mystical purposes. Survey respondents reported that pieces of the root can be worn in a gris-gris to protect the wearer from having to go to prison; they can be tied to a child to keep them healthy during the rainy season; they can be buried in a house to offer the household protection; and they can also be scattered in fields to help increase crop yields. Rhizophora spp. roots are also used informally as tools for cooking maafe (a Senegalese dish); to remove oysters from roots; and to remove snails from their shells. Mangrove roots are not typically sold or purchased.

\subsection{Indirect uses of mangroves}

In addition to utilizing mangroves directly, communities in the Sine Saloum Delta indirectly utilize mangroves through their collection of fish, clams, oysters, shrimp, honey, salt and shells (see Fig. 3). Fishery related activities are the primary source of income for $32.9 \%$ of survey participants (n 219).

\subsubsection{Fish}

When asked why mangroves are important, a Niominka Serere woman stated, "We only really know what mangroves do for fish, because we are Niominka" (Interview, October 2013). Inhabitants of the SineSaloum Delta particularly depend on fish., with fish being served at almost every meal; and by survey results, which show that $72.6 \%$ of respondent households collect fish (n 219). The frequency of fishing is dependent on the tides and the type of fishing, but nevertheless, 53.9\% of survey respondents stated that their households collect fish at a high frequency ( $n$ 219). As a rule, only men are fishermen in the SineSaloum Delta, whereas women are the primary fish sellers and processors. Fresh fish is sold and traded but also kept for consumption by the family. The price for fresh fish depends on the type and size of the fish caught, but is perceived as being expensive to purchase according to $72.6 \%$ of survey participants (n 219). Fish is also often dried. Households typically dry the fish in the sun within their households or on wooden racks in public areas. In one section of the Delta there are several large formal drying "ovens" that are used for drying and smoking fish caught by migrant fishermen.

\subsubsection{Clams}

Clam (Anadara senilis) collecting and processing is an activity reserved uniquely for women in the Sine-Saloum Delta. Women go out during periods of low tide and collect clams that are on the sea floor. Survey results indicate that $65.3 \%$ of all survey respondent households collect clams, with $50.7 \%$ collecting clams at a high frequency (n 219). However, clam collecting is dependent on the location of the village. It was reported that clams are not available for collection in one village and that the women that do collect clams from that village (5\%, n 40) go to other villages to collect them. Once collected, clams are steamed, removed from their shells and set out to dry in the sun. Once dried, they are sold at local markets or consumed by the household.

\subsubsection{Oysters}

Oyster (Crassostrea gasar/Crassostrea tulipa) collecting is a major activity in certain villages of the Sine-Saloum Delta. Out of all villages surveyed, 54.3\% (n 219) of respondent households collect oysters, with $95 \%$ (n 40) of households collecting in one village and $83.8 \%$ (n 37 ) collecting in another village. In a third village only $5 \%$ (n $\quad 40)$ of survey respondents reported that they collect oysters, and those that did stated that they go to other villages to collect them.

In general oysters are collected during the low tide after the rainy season is over (Interview, November 2013). During this time, there is a high frequency of oyster collection, with $37 \%$ (n 219) of survey respondents stating that they collect oysters at a high frequency.

Women, particularly those that belong to women's groups, are the primary oyster collectors. Raw oysters are sometimes sold to hotels throughout the delta, which in turn place them on restaurant menus for tourists. However, it is more typical for women to collect oysters for local use, steam them open, remove them from the shell and dry them in the sun prior to selling them in local markets. A dried kilo of oysters sold in local markets averages approximately XOF 3000. There was one reported group of men that collects and sells raw oysters to a restaurant in Dakar (Interview, October 2013).

\subsubsection{Shrimp}

Depending on the village, shrimp collection and processing is a major activity. Results indicate that $35.2 \%$ of all survey respondents collect shrimp (n 219). However, when disaggregated by village it can be seen that two villages have a high number of households collecting shrimp (97.5\% [n 40]; and 65\% [n 40]); whereas, there was no reported shrimp collection in a third village. 

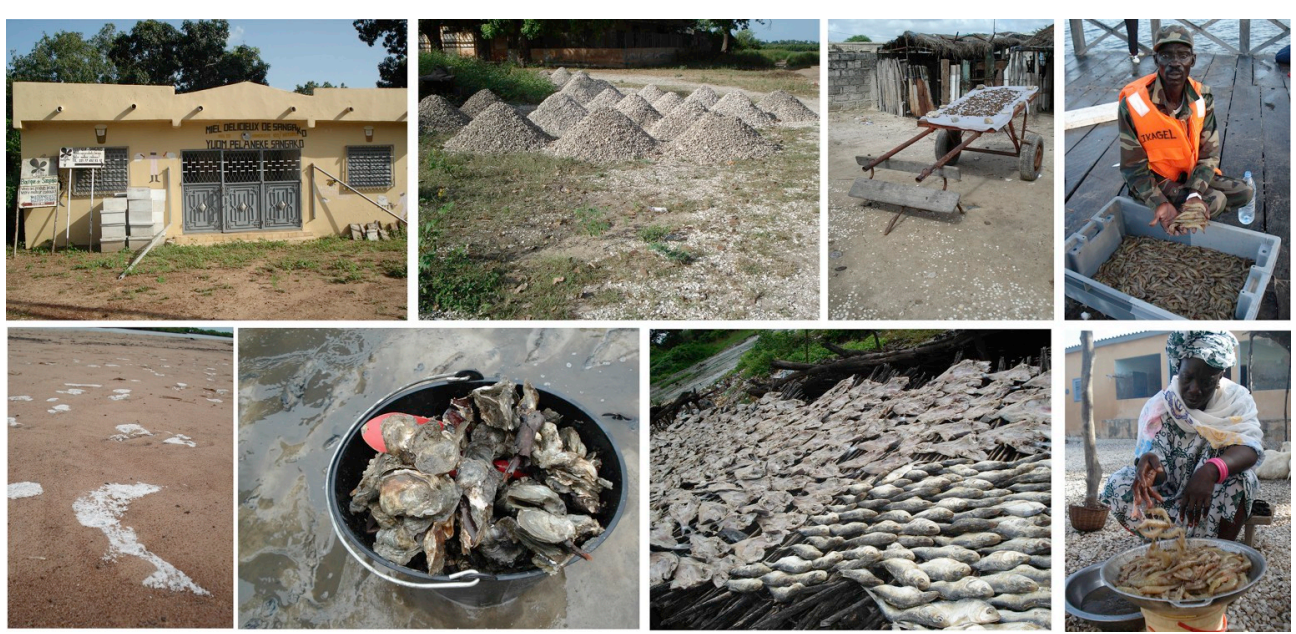

Fig. 3. Indirect mangrove use Top row, left to right: (1) Mangrove honey shop in the village, (2) Piles of shells being sold for construction purposes, (3) Shelled clams drying in the sun on top of a wagon, (4) Man holding fresh caught shrimp. Bottom row, left to right: (5) Mangrove salt collecting on the ground, (6) Fish drying on wood racks in the sun, (7) Bucket of oysters that were collected during a mangrove reforestation, (8) Woman selling shrimp at a local market. (Photographs: Laura Gallup).
The frequency of shrimp collection depends on the tides, the technique and the time of year. According to a shrimp fisherman, shrimp is collected at night by men only. It was also stated that the season runs from the month of August until January. During this period 32.9\% of survey respondent households collect shrimp at a high frequency. In informal discussions, one villager stated that 2-3 tons of shrimp are caught every night by their village. One village primarily practices the technique of seining to collect shrimp, whereas another village primarily practices the technique of deep-water shrimp collecting. As reported by villagers, people who seine often go out two times in the evening: once a few hours after the sun goes down, and then again before the sun rises. For deep-water shrimp collecting, the men take a boat out after the sun goes down and return to shore shortly after the sun rises. Shrimp is sold more often than it is consumed by families. The seined shrimp is often cleaned, dried and sold in local markets; whereasthe deep-water shrimp is more often sold fresh and exported.

\subsubsection{Honey}

Mangrove honey in the Sine-Saloum Delta is highly prized for its taste. While it is predominantly collected from "modern" hives, some mangrove honey is still collected in "traditional" hives. Mangrove honey cultivation is practiced in only certain locations within the Sine-Saloum Delta, however due to its popularity many households stated that they wished to cultivate it. For all villages surveyed, $16 \%$ of the respondents (n 219) stated that someone from their household collects mangrove honey. In one village, an international governmental organization helped establish a mangrove honey cultivation program that has over twenty beehives in the vicinity of the mangroves. This organization also helped the community establish a shop in which the mangrove honey is packaged and sold. In this village, $51.4 \%$ (n 37) of survey respondents reported that they collect mangrove honey.

\subsubsection{Salt}

According to survey results, $55.3 \%$ of survey respondent households collect salt (n 219). Women are the principle salt collectors in the SineSaloum Delta, and they collect salt during the dry season which typically runs February through May. The collection of salt ranges between low and high frequency, and is often sold at local markets. A "salt machine" used by women to sort and clean salt was observed in the household of one village Chief.

\subsubsection{Shells}

Shell middens of cultural importance and created over two-thousand years ago are prevalent throughout the Sine-Saloum Delta, and "artificial" islands created by these shell middens can be found. Shells are collected and used for construction and erosion prevention purposes throughout the Delta. For construction purposes, shells are mixed with cement in place of pebbles to make concrete. It was observed that most of the houses in one island village were made from this mixture.

For erosion prevention purposes, many island households place discarded shells on their property and in public places throughout the village. Clam and oyster shells were observed on the property of almost every household in one village. Men generally collect shells from clam and oyster collectors, but the shells are also quarried from the earth. Only $2.7 \%$ of households surveyed collect shells (n 219). However, these shells are more often sold in large quantities at markets, where they are purchased by construction workers. One gentleman from a village quarries shells and sells them in the village of Sokone for XOF 5500 per pile. Over 100 piles of shells were observed for sale in the Kaolack regional market.

\subsection{Mangrove management}

\subsubsection{Regulations}

In Senegal, mangrove use is governed under the Senegalese Forest Code Law n 98-03 and its Application Decree n 98-164. Under Article L.10 of the law, riparian populations are allowed to collect dead wood and straw, harvest fruits and plants, and use (green) wood to repair their households (Republique du Senegal, 1998). The law also states that mangroves may not be collected for commercial purposes (Article L.13) and that the right of use may be restricted or suspended by the Minister of Water and Forests in order to safeguard the forest (Article L.12) (Republique du Senegal, 1998). In order for mangroves to be used for commercial purposes, authorization must be given from the Ministry of Water and Forests, and a fee of XOF 500 for each cubic meter of wood sold must be paid (Interview, August 2013).

Despite the Forest Code Law, it was observed that there is much ambiguity in relation to the management of mangroves particularly around whether or not authorization is needed to use them. One village chief stated that mangrove cutting is completely forbidden within his village (Interview, October 2013). In other villages, an informal market for mangrove firewood was observed, with villagers buying wood from their neighbors or trading it for goods or services. In another village, the leader of an economic interest group stated that their village belonged to an association of five villages and that the cutting of mangroves was forbidden within each of the five villages (Interview, October 2013).

When asked if they have ever obtained authorization to use mangroves, $17.4 \%$ of survey respondents replied that they have (n 219). However, there were multiple responses when asked who gave them authorization. Responses ranged from the village chief, to the president of the Rural Community, the Ministry of Water and Forests, the President of an NGO, and to other people including family members. There 
were also a variety of responses when survey respondents were asked why they did not receive authorization. Responses ranged from "there are no laws", to "it is expensive", "we only use dead wood so it is not needed", "there aren't enough mangroves to use them", and "you only need authorization if they are being sold". This confusion about the regulation of mangroves was confirmed during an interview with a senior environmental agent. During the interview the agent stated that, "For the most part, mangroves are public property. However, mangrove management is confusing, it is all different. There are laws, but the laws depend on the zone that they are in. You must understand the zones and how government works in order to understand the management of mangroves" (Interview, August 2013).

In 2013 the Ministry of Water and Forests had six agents stationed within the Sine-Saloum Delta to enforce the laws of the Forest Code (Interview, August 2013). According to one interviewee, agents are supposed to patrol at least once a month to see if people are transporting or illegally gathering mangrove wood. However, in reality there are very little means by which agents are able to investigate such cases. It is often the case that agents do not have access to boats, and if they do they do have access to a boat, they do not have money to purchase fuel for the boats (Interview, August 2013). In discussing the capacity of agents of the Department of Water and Forests to manage the mangroves, one interviewee said that "There is only one agent for an entire arrondissement sometimes, and he only has a small motorcycle. They have roadblocks to check and see if people transport forest products. But people take their wagons and go around these road blocks" (Interview, August 2013). During an informal conversation one villager stated that "agents from the Department of Water and Forests do not come, so people can [collect wood]". Another interviewee stated that, "There is a huge problem with people cutting mangrove wood ... They go at sunset and cut it and bring it home" (Interview, September 2013). In addition, another way in which people bypass the law is through the practice of "bois tue", whereby people cut trees while they are green in order to have increased access to "legal" and "naturally occurring" firewood at a later date.

Because there are so few agents working at the Department of Water and Forests, a strategy the ministry employs to curtail the issue is by teaching Rural Communities how they can take care of themselves. They do this by encouraging and assisting Rural Communities to create different committees (Interview, August 2013). Belonging to a committee can encompass many different things, including belonging to a women's group, an association, a youth group, an NGO or organization committee and/or an economic interest group. When asked if they belong to a committee, $53.9 \%$ of survey respondents replied "yes" (n 219).

In order to incentivize the enforcement of the Forest Code Law, agents from the Ministry of Water and Forests are entitled to $30 \%$ of the fines collected from illegal mangrove use, with the remaining money going to the Rural Community (Interview, August 2013). Similarly, if a citizen (non-Ministry of Water and Forests agent) were to report someone using mangroves illegally, then the citizen who made the complaint would be entitled to $20 \%$ of the fines collected, the Ministry of Water and Forests would be entitled to $10 \%$, and the Rural Community would be entitled to the remaining funds (Interview, August 2013). In 2013, the Department of Water and Forests caught people illegally trying to sell mangrove wood in five different villages and fines for the illegal sale of mangrove wood ranged from XOF 50,000 to 150,000 (Interview, August 2013).

\subsubsection{Reforestation}

Throughout the Sine-Saloum Delta, the Senegalese Ministry of Water and Forests, international governmental organizations, nongovernmental international organizations, and local groups mobilize people to participate in reforestation events as a form of mangrove management (see Fig. 4). These events vary by organization and location, but generally consist of educational meetings, species selection, the collection of fruit and propagules, the planting of mangroves and the monitoring of reforested areas.

3.3.2.1. Meetings. When asked if they have ever attended a meeting about mangroves, half of the respondents responded that they have $(54.3 \%, n$ 219). Meetings are generally led by organizations or NGOs prior to the reforestation to educate and sensitize communities about mangrove management. Film screenings and theatre troupes have been used to help educate the communities. Film projections are a popular NGO sensitization method, and about $70 \%$ of survey respondents reported that they have seen a film screening within their community about mangrove management.

3.3.2.2. Species selection and collection. Rhizophora spp. and Avicennia germinans are the only mangrove species planted within the Delta. Rhizophora spp. is often the preferred species for reforestation because of its economic value, fuelwood utility, and its ease in planting when compared to Avicennia germinans (Interview, November 2013). Mangrove planting takes place during the rainy season and coincides with field crop planting. Rhizophora spp. is typically planted just until the end of the rainy season and Avicennia germinans can continue to be planted a little longer (Interview, November 2013). When planting, Rhizophora spp. propagules are typically collected and planted directly into the ground, whereas Avicennia germinans wildlings are collected and planted, or the fruit are grown in a mangrove nursery and then they are out-planted. Half of the total respondents said that they have collected mangrove fruit or propagules, with a fairly equal distribution between males (53.3\%, n 107) and females (47.3\%, n 112).

Organizations and NGOs are instrumental in influencing the species of mangrove that is being planted during reforestation events. In one instance, a village Chief, the head of an NGO and an Agent from the Department of Water and Forests were observed negotiating the species of mangrove that should be planted within the village. The Village Chief wanted to plant Rhizophora spp. because his villagers utilize that species more often as fuelwood. However, the NGO head and the Ministry Agent persuaded him to plant Avicennia germinans so that there would be a higher mangrove survival rate. In addition, the Mangrove Project Coordinator at one NGO stated that "[our organization] is concerned with planting Avicennia germinans. People don't plant Avicennia germinans because it is more difficult. People plant Rhizophora spp. where Avicennia germinans should go" (Interview, 13 November 2013). And in an interview with the Mangrove Project Coordinator of another organization, it was stated that, "[our organization] plants both Rhizophora spp. and Avicennia germinans. When choosing the type of plant to use, we talk to the people. First we ask people 1) ecologically: What is the best type of plant for the area, what grows the best? And then, 2) economically, what is the utility of the species? Will it play an economic role for the populations?" (Interview, November 2013).

3.3.2.3. Planting. Results indicate that overall most survey participants have planted mangroves at least once $(68.9 \%, \mathrm{n} \quad 219)$, with $22.8 \%$ (n 179) having planted mangroves six or more times. When broken down by village, $97.3 \%$ ( $n$ 37) of survey participants in one village planted mangroves at least once and 54\% planted them six or more times. In one village there was a higher number of females that participated in planting than males, with the opposite being true in another village. Survey participants who did not participate in mangrove reforestation events ( $n$ 68) said that their lack of participation was due to their unavailability when reforestation activities took place $(39.7 \%)$, their elderly age (17.6\%), or their lack of awareness about when reforestation events took place $(16.2 \%, \mathrm{n} 219)$.

When asked if mangrove planting is difficult or easy, $36.1 \%$ (n 219) of survey participants said they thought it was difficult. Difficulties included: sinking (sometimes two feet deep) in the mud and getting dirty and wet, the physically demanding work on their bodies, the lack of technical knowledge, the collection of Rhizophora spp. 


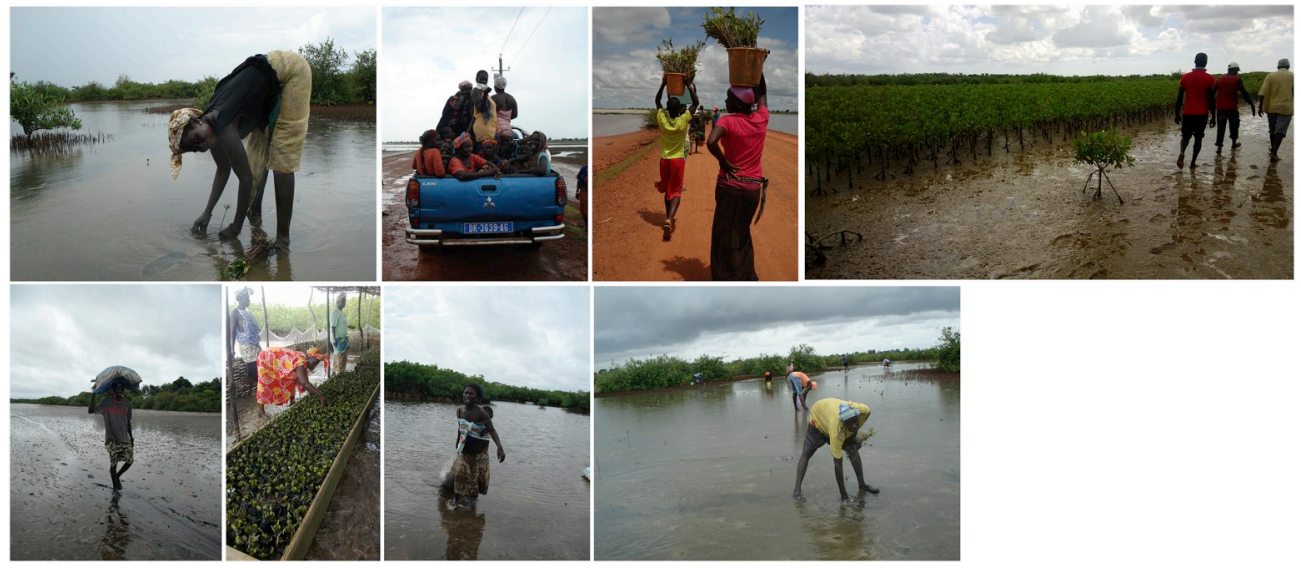

Fig. 4. Participation in mangrove rehabilitation. Top row, left to right: (1) Woman planting Avicennia germinans wildlings, (2) WWF truck transporting people to the rehabilitation site, (3) Teenagers transporting Avicennia germinans wildlings to the rehabilitation site, (4) Improved cooking stove for sale in the town of Sokone. Bottom row, left to right: (5) Man transporting Rhizophora spp. propagules to the rehabilitation site, (6) Woman working in an Avicennia germinans nursery, (7) Woman with a baby on her back transporting Rhizophora spp. propagules to the rehabilitation site, (8) Man planting Avicennia germinans wildlings. (Photographs: Laura Gallup). propagules, the low survival rate, having to leave household duties, the lack of means, and the hot sun.

3.3.2.4. Monitoring. Monitoring of the mangroves after plantation is an imperative step in mangrove rehabilitation. When surveyed, 58.9\% (n 219) of survey respondents replied "yes" when asked if they have ever monitored the mangroves after planting. However, it was observed that there are typically specific people who are responsible for monitoring mangrove sites. In one interview it was stated that, “... follow-up is super important and people are specifically responsible for follow-up. They are very organized. There are people who are responsible for follow-up because not all people know how to do this. For example, out of every 100 planters, 10 are responsible for follow-up" (Interview, September 2013). However, it was also stated during informal conversations with women in one village that they will plant the mangroves but once they are done planting they are done and they do not go back to monitor them.

3.3.2.5. Committees. Findings indicate that there may be a tendency for NGOs and organizations to work with village committees when they initiate mangrove rehabilitation projects. According to the Mangrove Project Coordinator at one NGO, "we work mostly with women's groups because they are the most vulnerable, and because they are the most organized. When we go into a village we find groups that are organized and working with trees, mangroves, or the environment and more often than not these are women's groups". (Interview, November 2013). Similarly, in an interview with another NGO it was stated that, "we work mostly with village chiefs, professional groups, women and youth organizations" (Interview, September 2013).

3.3.2.6. Payment for participation. In order to motivate people to participate in mangrove reforestation events, most organizations within the Sine-Saloum Delta provide some sort of financial or material incentive. These incentives are to help encourage participation in both mangrove propagule and fruit collection, and in mangrove planting. Some organizations provide funding to communities for supplies (gas, boats, buckets, wagons, horse or donkey carriages, vehicles, lunch for participants, food for horses and/or donkeys); or they provide food such as rice, corn and oil in exchange for community involvement. Other organizations pay participants directly for their participation. Forty percent of all survey participants (n 219) reported that they had received payment to plant mangroves; with percentages ranging from $31.8 \%$ in one village ( $n$ 22) to $70.3 \%$ ( $n \quad 37$ ) in another village. Survey participants were not asked which organizations offered them payment for their participation. The amount that organizations paid participants to plant mangroves typically ranged from XOF 500- XOF 2000 per day.

Interview and survey results reveal that payments made by organizations have made it difficult for people to participate without the payment. An informal conversation with one villager revealed that people within the village used to plant mangroves for free before organizations came and started giving money for their participation. According to a Mangrove Project Coordinator at one NGO, “... people are starting to expect to get paid to do reforestation, and it is difficult to get people to participate otherwise" (Interview, November 2013). The Mangrove Project Coordinator at a different organization stated "It is not easy to mobilize people to reforest. This is because of the manner of intervention of other NGO's. Other [NGOs] pay people to participate, and sometimes other organizations give XOF 5000 per person per day. [Our organization] 'motivates' people, but they don't give too much ... investors condition NGOs. [NGOs] are told that they must work in certain villages and do a certain amount of planting [in order to get funding]".

However, some data suggests that it is less about the payment and more about having the means to get the job done. During an informal conversation, one villager stated that, "People want some kind of money to plant. You need to take a boat in order to get transplants and you need to go far to do that, and that costs gas money. You can pick [propagules and fruit to plant] in the area, but there [may not be] that many and they [may not be] the best ones. People would participate if they were given lunch and if the gas money for the boat was paid, we don't necessarily need to be paid a lot of money at all". This was supported in an interview with a female village leader who said, "Propagules aren't close by, that's how badly degraded the mangroves are. We have to get transportation, a wagon, a boat or a horse and carriage. But we also need gas for the boat, food for the group and food for the horse. Additionally, we cannot take people from their family [and expect them] to volunteer and plant mangroves. There are a lot of difficulties with this. [A local organization] has only one canoe for seven villages; you cannot plant mangroves with one boat. There needs to be good transportation. If we go and collect propagules, we have to transport the propagules and get them planted before they go bad and die" (Interview, 5 September 2013). And according to another woman, "People want to plant and do work but there is no means to do it, so they cannot do anything" (Interview, September 2013).

Results indicate that people may be reluctant to participate in mangrove rehabilitation outside of the context of an organization or NGO run mangrove project. When asked about participation in mangrove rehabilitation, one village chief said, "We planted [mangroves] with [an organization] last year and the year before ... but no one planted this year because no partner came. When partners come, everyone plants" (Interview, October 2013). Similarly, 19\% of total respondents stated that their future participation was contingent on whether or not a project brings a reforestation project to their village.

3.3.2.7. Survival rate. Interviews suggest that mangrove reforestation in the Delta has a low survival rate. The low survival rate is discouraging to villagers who participate in reforestation. According to one 
interviewee, "we planted last year, and all the trees are dead. It is super hard on [people who] plant year after year [to] see the trees all dead all the time" (Interview, September 2013). The northern part of the delta is considerably saltier than other areas of the delta, and one interviewee said that Rhizophora spp., which is not very salt tolerant, does not always survive (Interview, November 2013). In an informal conversation with one villager, it was stated that the Avicennia germinans that the village planted had a $40 \%$ survival rate. According to one community group leader, an Avicennia germinans nursery was started because reforestations using Rhizophora spp. species were not successful (Interview, September 2013). According to an interview with a representative from the "Plant Your Tree" initiative, "there has been an 85 percent success rate, but now we are planting in less favorable and more damaged zones and it is more complicated" (Interview, September 2013). A leader in one village said, "We did a reforestation last year, and it all died because it was the end of the rainy season" (Interview, 28 October 2013).

\section{Discussion}

Results from this study indicate that fuelwood is the most important extractive use for mangroves within the Sine-Saloum Delta, Senegal. Findings are consistent with those of several other studies in Senegal and elsewhere (Conchedda et al., 2011; Dahdouh-Guebas et al., 2000; Dayalatha and Ali, 2019; Teka et al., 2018). The importance of mangrove fuelwood is determined by the large number of households that use dead mangrove wood, the high frequency of collection of dead mangrove wood, and the preference for mangrove wood as fuelwood.

The reported levels of dead mangrove wood being collected for fuelwood may indicate that some of it is being collected illicitly. It was beyond the scope of this study to carry out a structured examination of the quantity of dead wood being collected or the timing of collection, however results indicate that larger than usual quantities of dead mangrove wood are being collected by people just prior to the rainy season and also for the processing of fish caught by migrant fishermen. Depending on the amount of wood being collected at a given time, it might be questionable that such large amounts of dead wood are naturally occurring. In addition, there were indications of this illicit collection in reports of the practice of "bois tue", whereby people cut trees while they are green in order to have increased access to "legal" and "naturally occurring" firewood at a later date. In addition, the higher sales price for dead mangrove wood and the preference for mangrove firewood may make it more attractive for people to collect it illicitly. Similarly, other scholars have found that an illicit trade exists in the region (Carney et al., 2014; Fent et al., 2019).

High levels of mangrove fuelwood collection may also have negative implications on the environment, as was found by other scholars (Carney et al., 2014; Fent et al., 2019). The practice of "bois tue" in particular may be damaging. Dahdouh-Guebas et al. (2004) and Ellison and Farnsworth (1996) found that even small scale cutting of mangroves could kill the trees. In a study that took place in Kenya, links were found between the cutting of Rhizophora spp. and an increase in siltation around the trees (Dahdouh-Guebas et al., 2004). This increase in siltation, even when the incidence of mangrove cutting is low or has completely ceased, has been shown to be enough to kill the trees (Dahdouh-Guebas et al., 2004). In addition, the low number of households with improved stoves may indicate that few measures are in place to reduce household consumption of mangrove wood for fuelwood. Despite micro-credit programs in several villages, improved stoves are underutilized and large quantities of fuelwood are being consumed inefficiently in open-pit stoves.

Fish, clam, oyster and shrimp collection is the second most important use of mangroves within the Delta due to the large number of households that collect these items along with their high frequency of collection. A study by Conchedda et al. (2011) found that the annual revenues from mangrove resources in Senegal accounted for one-third of the gross national income (GNI) per capita, and that the collection and sale of oysters and clams were the top two principal uses of mangrove resources. Studies have found that mangrove areas may be a good predictor of fishery catches overall (Carrasquilla-Henao and Juanes, 2017; Diop et al., 2016). Should the high demand for dead mangrove wood that was found in the present study negatively impact the mangrove ecosystem, there could be negative consequences for these fishery resources as well. It was surprising to find that green mangrove wood was not used to a much higher degree than was reported. The reason for this may be because mangrove wood lasts a long time and people do not need to replace it very frequently when using it for building purposes. It was observed that many houses were built out of cement or mud, and that frequently tin roofs were used. These alternative construction materials may be part of the reason why mangrove wood is used less than in the past.

In relation to mangrove management, a key finding from this study is that despite the Forest Code Law and its implementing decree, there is much ambiguity in relation to the management of mangroves, particularly around whether authorization is needed to use the mangroves. Another key finding is the lack of means by which regulations created to protect the mangroves can be enforced. People apprehended for illegal use of mangroves are fined. However, few environmental agents are available within the Delta to enforce the laws; and the environmental agents who are present in the region have insufficient capacity to regularly monitor all mangrove areas. Findings from this study suggest that the local population is aware of these limitations and in some cases take advantage of them. Some individuals collect mangrove products in ways that they know they should not, anticipating that it is unlikely that they will be apprehended; others bypass roads with enforcement checkpoints.

A further key finding of this study is that mangrove reforestation is a robust activity within the Sine Saloum Delta. Large numbers of both males and females have collected mangrove propagules and fruit; even more have participated in mangrove planting. Study results suggest that financial compensation plays a significant role in motivating people in this participation, and that international organizations and NGOs have been the main drivers of this expectation of payment. The results of this study indicate that a consequence of this compensation is that people are increasingly willing to participate in mangrove reforestation only if they are compensated.

The success rate of the mangrove planting is unclear, but results suggest that there is often a low survival rate. Other studies have shown that mangrove planting that is not underpinned by science may lead to a loss of mangroves (Elster, 2000; Kodikara et al., 2017). The low survival rate in the Sine Saloum Delta may be due to villagers being mobilized to participate in mangrove planting events with monetary incentives as their primary driving force.

\section{Conclusion}

This paper utilizes quantitative survey data and qualitative field research to evaluate mangrove use and management within the SineSaloum Delta, Senegal. Results indicate that the harvesting of dead mangrove wood for fuelwood is the most important extractive use of mangroves within the Delta; and that fish, clam, oyster, and shrimp collection is the second most important use of mangroves. The reported levels of dead mangrove wood being collected for fuelwood suggest that some of it is being collected illicitly; and that the high levels of collection may lead to negative environmental impacts. Despite Senegal's Forest Code Law, there is ambiguity in relation to mangrove management in the country, particularly around whether authorization is needed to use the mangroves. There is a lack of means for mangrove protection to be enforced within the Sine Saloum Delta. Results also indicate that mangrove reforestation is a robust activity in the region, and that financial incentive from international organizations and NGOs plays a significant role in motivating community participation in such initiatives. 


\section{Funding}

Peace Corps Senegal provided financial support for the conduct of the research. Peace Corps Senegal had a minor role in the study design and data collection arrangements. Peace Corps Senegal had no role in the analysis and interpretation of data, the writing of this article, or the decision to submit it for publication. Water Charity provided partial financial support for one reforestation event hosted by Peace Corps Senegal during the time when fieldwork was conducted. Water Charity had no role in the study design, data collection arrangements, analysis, interpretation of data, writing of this article or the decision to submit it for publication.

\section{Declaration of competing interest}

The authors declare that they have no conflicts of interest.

\section{Acknowledgements}

The authors would like to thank Chris Hedrick, Demba Sidibe, and Cherif Djitte from Peace Corps Senegal for making this project possible; Abdou Aziz Diedhiou and all the staff from WWF for logistical help and mentoring in the field; the communities of Guague Bocar, Ndorong Log, Djirnda, Bambougar El Hadji, Sangako and Bossingkang for their participation and kindness; and Dr. John McPeak from Syracuse University, and Dr. Paul Hirsh from the State University of New York College of Environmental Science and Forestry, for their early guidance.

\section{Appendix A. Supplementary data}

Supplementary data related to this article can be found at https:// doi.org/10.1016/j.ocecoaman.2019.105001.

\section{References}

ADG, 2011. La mangrove, un ecosysteme a proteger... Guide pratique a l'usage des Communautes Rurales du Delta du Saloum. Senegal. Capitalisation de l'experience de l'ONG ADG. Thies, Senegal.

Alongi, D.M., Webster, T., Morison, J., Herr, A., Abel, N., Taylor, B., Clark, E., Stone, P., 2016. Present State and Future of the World's Mangrove Forests 10 Irrigated Agriculture: Development Opportunities and Implications for Northern Australia.

Balla Dieye, E.H., Tahirou Diaw, A., Sane, T., Ndour, N., 2013. Dynamique de la mangrove de l'estuaire du Saloum (Senegal) entre 1972 et 2010. Cybergeo Eur. J. Geogr. Environ. Nature. Paysage, document 629. January 9. https://doi.org/10. 4000/cybergeo. 25671.

Bandaranayake, W., 1998. Traditional and medicinal uses of mangroves. Mangroves Salt Marshes 2, 133-148.

Bosire, J.O., Dahdouh-Guebas, F., Walton, M., Crona, B.I., Lewis, R.R., Field, C., Kairo, J. G., Koedam, N., 2008. Functionality of restored mangroves: a review. Aquat. Bot. 89, 251-259. https://doi.org/10.1016/j.aquabot.2008.03.010.

Carney, J., Gillespie, T.W., Rosomoff, R., 2014. Assessing forest change in a priority West African mangrove ecosystem: 1986-2010. Geoforum 53, 126-135. https://doi. org/10.1016/j.geoforum.2014.02.013.

Carrasquilla-Henao, M., Juanes, F., 2017. Mangroves enhance local fisheries catches: a global meta-analysis. Fish Fish. 18, 79-93. https://doi.org/10.1111/faf.12168.

Cisse, A.T., Ghysel, A., Vermeulen, C., 2004. Systemes de croyances Niominka et gestion des ressources naturelles de mangrove. In: International Symposium Tropical Forests in a Changing Global Context. Royal Academy of Overseas Sciences, Brussels, pp. 307-332.

Conchedda, G., Lambin, E.F., Mayaux, P., 2011. Between land and Sea: livelihoods and environmental changes in mangrove ecosystems of Senegal. Ann. Assoc. Am. Geogr. $101,1259-1284$.

Corcoran, E., Ravilious, C., Skuja, M., 2007. Mangroves of Western and Central Africa. UNEP-Regional Seas Programme/UNEP-WCMC, Cambridge, UK.

Dynamique et usages de la mangrove dans les pays des rivieres du sud (Du Senegal a la Sierra Leone). In: Cormier-Salem, M.-C. (Ed.), 1994. Actes de l'Atelier de Travail de Dakar Du 8 Au 15 Mai. ORSTOM Editions, Paris.

Cormier-Salem, M., Panfili, J., 2016. Mangrove reforestation: greening or grabbing coastal zones and deltas? Case studies in Senegal ${ }^{\S}$. Afr. J. Aquat. Sci. 41, 89-98. https://doi.org/10.2989/16085914.2016.1146122.

Cormier-Salem, M.C., 2017. Let the women harvest the mangrove. carbon policy, and environmental injustice. Sustain. Times 9. https://doi.org/10.3390/su9081485.

Dahdouh-Guebas, F., Hettiarachchi, S., Lo Seen, D., Batelaan, O., Sooriyarachchi, S., Jayatissa, L.P., Koedam, N., 2005. Transitions in ancient inland freshwater resource management in Sri Lanka affect biota and human populations in and around coastal lagoons. Curr. Biol. 15, 579-586. https://doi.org/10.1016/j.cub.2005.01.053.

Dahdouh-Guebas, F., Mathenge, C., Kairo, J.G., Koedam, N., 2000. Utilizaition of mangrove wood products around Mida Creek (Kenya) Amongst subsistence and commercial users. Econ. Bot. 54, 513-527.

Dahdouh-Guebas, F., Van Pottelbergh, I., Kairo, J., Cannicci, S., Koedam, N., 2004. Human-impacted mangroves in Gazi (Kenya): predicting future vegetation based on retrospective remote sensing, social surveys, and tree distribution. Mar. Ecol. Prog. Ser. 272, 77-92. https://doi.org/10.3354/meps272077.

Dahdouh-Guebas, F., Vrancken, D., Ravishankar, T., Koedam, N., 2006. Short-term mangrove browsing by feral water buffalo: conflict between natural resources, wildlife and subsistencce interests? Environ. Conserv. 1-7. https://doi.org /10.1017/S037689290.

Datta, D., Chattopadhyay, R.N., Guha, P., 2012. Community based mangrove management: a review on status and sustainability. J. Environ. Manag. 107, 84-95. https://doi.org/10.1016/j.jenvman.2012.04.013.

Dayalatha, W.K.V., Ali, S.K.M., 2019. The use of mangroves as a source of fire wood: a socio-economic study on selected mangroves in southern Sri Lanka. J. Soc. Sci. Humanit. Rev. 3, 175. https://doi.org/10.4038/jsshr.v3i3.14.

Dia, I.M., 2012. Vulnerability Assessment of Central Coastal Senegal (Saloum) and the Gambia Marine Coast and Estuary to Climate Change Induced Effects. Banjul, The Gambia.

Diop, B., Sanz, N., Blanchard, F., Walcker, R., Diop, B., Sanz, N., Blanchard, F., Walcker, R., Gardel, A., 2016. The Role of Mangrove for the French Guiana Shrimp Fishery to Cite This Version: HAL Id: Hal-01383024 Octobre 2016 the Role of Mangrove for the French Guiana Shrimp Fishery.

Diop, E.S., Soumare, A., 1999. A perspective on integrated management of a tropical coastal area: the case of the Saloum biosphere reserve (Senegal, West Africa). Coast. Manag. 27, 317-328. https://doi.org/10.1080/089207599263721.

Donato, D.C., Kauffman, J.B., Murdiyarso, D., Kurnianto, S., Stidham, M., Kanninen, M., 2011. Mangroves among the most carbon-rich forests in the tropics. Nat. Geosci. 4, 293-297. https://doi.org/10.1038/ngeo1123.

Duke, N.C., Meynecke, J.-O., Dittmann, S., Ellison, A.M., Anger, K., Berger, U., Cannicci, S., Diele, K., Ewel, K.C., Field, C.D., Koedam, N., Lee, S.Y., Marchand, C., Nordhaus, I., Dahdouh-Guebas, F., 2007. A world without mangroves? Science 80, 317, 41-42walters.

Ellison, A.M., Farnsworth, E.J., 1996. Anthropogenic disturbance of caribbean mangrove ecosystems: past impacts, present trends, and future predictions. Biotropica 28, 549-565.

Elster, C., 2000. Reasons for reforestation success and failure with three mangrove species in Colombia. For. Ecol. Manage. 131, 201-214. https://doi. org/10.1016/S0378-1127(99)00214-5.

Fall, M., De, B., 2009. S'adapter a la Degradation de l'environnement dans le Delta Du Saloum: variabilite des strategies chez les femmes soces et niominkas du Senegal. VertigO 9, 1-7.

Fall, M., Dime, M.N., Sarr, C.O., 2009. Emergence of an Environmental Citizenship in Senegalese Rural Areas: Local Development Initiatives by the Fannabara Association in Missirah (Fatick, Senegal).

Fent, A., Bardou, R., Carney, J., Cavanaugh, K., 2019. Transborder political ecology of mangroves in Senegal and the Gambia. Glob. Environ. Chang. 54, 214-226. https:// doi.org/10.1016/j.gloenvcha.2019.01.003.

Field, C.D., 1998. Rehabilitation of mangrove ecosystems : An overview, 37, 383-392.

Goodman, L.A., 1961. Snowball sampling. Ann. Math. Stat. 148-170.

Kairo, J.G., Dahdouh-Guebas, F., Bosire, J., Koedam, N., 2001. Restoration and management of mangrove systems- a lesson for and from the East African region. South Afr. J. Bot. 67, 383-389.

Kodikara, K.A.S., Mukherjee, N., Jayatissa, L.P., Dahdouh-Guebas, F., Koedam, N., 2017. Have mangrove restoration projects worked ? An in-depth study in Sri Lanka. Restor. Ecol. 25, 705-716. https://doi.org/10.1111/rec.12492.

Kovacs, J.M., 1999. Assessing mangrove use at the local scale. Landsc. Urban Plan. 43, 201-208.

Lavieren, H. Van, Spalding, M., Alongi, D.M., Kainuma, M., Clusener-Godt, M., Adeel, Z., 2012. Securing the future of mangroves. Policy Brief.

Lewis III, R.R., Gilmore, R.G., 2007. Important considerations to achieve successful mangrove forest restoration with optimum fish habitat. Bull. Mar. Sci. 80, 823-837.

Ndour, N., Dieng, S., Fall, M., 2012. Rôles des mangroves, modes et perspectives de gestion au Delta du Saloum (Senegal). Vertigo-Electr. J. Environ. Sci. 11.

Nguyen, T.P., Luom, T.T., Parnell, K.E., 2017. Mangrove transplantation in brebes regency, Indonesia: lessons and recommendations. Ocean Coast Manag. 149, 12-21. https://doi.org/10.1016/j.ocecoaman.2017.09.006.

Nguyen, T.P., Van Tam, N., Quoi, L.P., Parnell, K.E., 2016. Community perspectives on an internationally funded mangrove restoration project: kien Giang province, Vietnam. Ocean Coast Manag. 119, 146-154. https://doi.org/10.1016/j.ocec oaman.2015.10.008.

Oanda, 2014. Oanda Currency Converter. https://www1.oanda.com/currency/convert er/.

Republique du Senegal, 1998. Code forestier, loi 98/03 du 08 janvier 1998.

Romañach, S.S., DeAngelis, D.L., Koh, H.L., Li, Y., Teh, S.Y., Raja Barizan, R.S., Zhai, L., 2018. Conservation and restoration of mangroves: global status, perspectives, and prognosis. Ocean Coast Manag. 154, 72-82. https://doi.org/10.1016/j.ocec oaman.2018.01.009.

Sall, I., Durin, G., 2013. Oceanium Dakar: the daily struggle for the integrated community-based protection of West Africa's marine and coastal ecosystems. Field Actions Sci. Rep. 19-25 [Online]. 
Stone, K., Bhat, M., Bhatta, R., Mathews, A., 2008. Factors influencing community participation in mangroves restoration: a contingent valuation analysis. Ocean Coast Manag. 51, 476-484. https://doi.org/10.1016/j.ocecoaman.2008.02.001.

Teka, O., Houessou, L.G., Djossa, B.A., Bachmann, Y., Oumorou, M., Sinsin, B., 2018 Mangroves in Benin, West Africa: threats, uses and conservation opportunities. Environ. Dev. Sustain. 1-17. https://doi.org/10.1007/s10668-017-0075-x.

Tongco, M.D.C., 2007. Purposive sampling as a tool for informant selection. Ethnobot. Res. Appl. 5, 147-158. https://doi.org/10.17348/era.5.0.147-158.

Valiela, I., Bowen, J.L., York, J.K., 2001. Mangrove forests: one of the world's threatened major tropical environments. Bioscience 51, 807. https://doi. org/10.1641/0006-3568(2001)051[0807:MFOOTW]2.0.CO;2.

Walters, B.B., Ronnback, P., Kovacs, J.M., Crona, B., Hussain, S.A., Badola, R., Primavera, J.H., Barbier, E.B., Dahdouh-Guebas, F., 2008. Ethnobiology, socio- economics and management of mangrove forests: a review. Aquat. Bot. 89, 220-236. https://doi.org/10.1016/j.aquabot.2008.02.009.

Walton, M.E.M., Samonte-Tan, G.P.B., Primavera, J.H., Edwards-Jones, G., Le Vay, L., 2006. Are mangroves worth replanting? The direct economic benefits of a community-based reforestation project. Environ. Conserv. 33, 335. https://doi.org/1 $0.1017 /$ S0376892906003341.

Weigel, J.-Y., Feral, F., Cazalet, B., 2011. Governance of marine protected areas in the least-developed countries. Case studies from West Africa. In: FAO Fisheries and Aquaculture Technical Paper, p. 77pp. Rome.

Weigel, J., Dahou, T., 2007. La gouvernance locale et ses impasses, Les aires marines protegees d'Afrique de l'Ouest: Gouvernance et politiques publiques. Presses Universitaires de Perpignan, Perpignan. 